\title{
Construction of an Origin: A Study of V. S. Naipaul's Trilogy on India
}

\author{
K. S. Saradhambal ${ }^{*}$ \\ Assistant Professor and Head, Department of English, Sri Vasavi College, Erode, India; \\ saradhabas@gmail.com
}

\begin{abstract}
The cosmopolitan life in this modern era has transformed people from all walks of life to all the corners of the world. This scenario is more exposed when one happens to be a writer. V.S. Naipaul, an accomplished writer of postmodern times, is one of the best examples of cosmopolitan writers. His writing serves as a platform to express his state of being. His Trilogy on India, the place of his origin serves as a testimony to the topic taken for discussion. This paper attempts to analyse Naipaul's reinvention of his origin in his first book on India, An Area of Darkness. Though he yearns for an emotional connection with India, his Western outlook towards the place of his origin is more of darkness. This darkness in his mind fades away to rediscovery of the truth of India in the third book on India: A Million Mutinies Now. Hence it is worth to dwell into the darkness of the writer's personal revelation of the external pattern. There is a paradigm shift from darkness to rediscovery of his origin.
\end{abstract}

Keywords: Attitudinal Change, Disinheritance, Origin, Universality

\section{Introduction}

Naipaul takes his own life as the theme of his writings, especially his Trilogy on India includes this autobiographical feature. His first book on India, An Area of Darkness (1964) reflects his anxieties about India. The physical reality of India from the western point of view makes him consider India as an area of darkness though more explicitly this expresses his soul's darkness towards his origin. His anger stems from his sense of disinheritance of the place. The struggle within himself between his upbringing and his inexperienced inheritance brings him again to India which resulted in his second book on India, titled, India: A Wounded Civilization (1977). Naipaul carries his wounded soul with him and laments over the moral chaos which every Indian faced after Independence. His third book, India: A Million Mutinies Now (1990) is centred on his perception on history, religion and truth of the nation. The authenticity of the novel is emphasised through many encounters with the people of India. His directness in reporting the stories, brings out the truthfulness of the place. His vision of India is transformed from anger and disillusionment to understanding and accepting the reality of the country of his origin, and strikes a deeper connection with it.

\section{State of Non Indian}

Naipaul's ancestors were Brahmins who immigrated to Trinidad from Varanasi in Uttar Pradesh. Trinidad is one of the islands in West Indies where Indians migrated to as indentured labourers during the British rule. His acquaintance with India was very vague, had heard of it only from his parents. He has romanticised about India since his childhood.

And India had in a special way been the background of my childhood. It was the country from which my grandfather came, a country never physically described

* Author for correspondence 
and therefore never real, a country out in void, beyond the dot of Trinidad, and from it our journey had been final [1].

The customs and rituals of their origin are strictly followed by their family. Every work they engage in and the place in which they live naturally evolve from their inheritance. The writer aptly registers this state in his Nobel Lecture:

We made no inquiries about India or about the families people had left behind. When our ways of thinking had changed and we wished to know, it was too late. I know nothing of the people on my father's side; I know only that some of them came from Nepal. Two years ago a kind Nepalese who like my name sent me a copy of some pages from an 1872 gazetteer-like British work about India, Hindu castes and Tribes as represented in Benares; the pages listed, among a multitude of names, those groups of Nepalese in the holy city of Banaras who carried the name Naipaul. That is all that I have [2].

Naipaul's journey to India is basically in search for meaning of life but remains a mystery to him during his first visit. He tries to bridge the gap between an unknown past and the present. He wants to develop a deep connection with his origin, for which he comes back to India often. These journeys are undertaken to assimilate the new land which is in his unconscious mind. He writes in An Area of Darkness, "India lay about us in things-in a string bed or two, grimy, tattered... in brightly coloured pictures of deities on pink lotus or radiant against Himalayan snow; ... in its artefacts India existed whole in Trinidad" [1].

Naipaul's visit to the village of his grandfather evokes his submerged memories. But the land remains outside his experience. Instead of illumination, it takes him further into darkness. It remains incomprehensible because of his Western intelligence. He registers this in An Area of Darkness:

India had not worked its magic on me. It remained the land of my childhood, an area of darkness: like the Himalayan passes, it was closing up again, as fast as I withdrew from it, into a land of myth: in second to exist in the timelessness which I had imagined as a child, into which for all that I walked on Indian earth, I knew I could not penetrate... In a year I had not learned acceptance. I had learned my separateness form India, and was content to be a colonial, without a past, without ancestors." [1].

Naipaul undergoes a different sensation in Bombay, the place of his first visit. For the first time, he feels that he is one among the crowd. There is no special treatment which he always receive in other places:
To be an Indian in England was distinctive, in Egypt it was more so. Now in Bombay I entered a shop or a restaurant and awaited a special quality of response. And there was nothing. It was like being denied part of my reality. Again and again I was caught. I was faceless. I might sink without a trace into that Indian crowd... recognition of my difference was necessary to me. I felt the need to impose myself, and didn't know how [1].

Though he wants to make a physical connection with the place, mentally he is far away. In spite of his upbringing and his ancestry, this totally new physical appearance hinders him to get into one. This forms the basis for the beginning of his anxiety. In the concluding paragraph of An Area of Darkness he writes:

It was only now, as my experience of India defined itself more properly again my homelessness, that I saw how close in the past year I had been to the total Indian negation, how much it had become the basis of thought and feeling. And already, with this awareness in a world where illusions could only be a concept and not something felt in the bones, it was slipping away from me [1].

The anxiety in him makes him visit India subsequently. He wants to make deeper connections than to be indifferent to it. Naipaul expresses this ambivalent state in his next book on India: A Wounded Civilization, "I cannot travel only for the sights. I am at once too close and too far" [3].

\section{Negotiation with Changing Realities}

The attitudinal change can be witnessed through the lines "A year before I might have been appalled by what and was seeing. But my eye had changed. The village looked unusually prosperous; it was even picturesque" [1]. At an intellectual level, he thinks of the crisis of a wounded and old civilization that has become aware of its inadequacies. But at the same time he is aware of the destruction and depletion of the creative energy because of the British rule. He carries his wounded soul wherever he goes and laments of how once meaningful forms now appear empty. Even in Trinidad, differences in origin and background result in gaps between two cultures and thereby lead to conflicts between two communities. He is now able to connect with reality and understand the place now he visits with the place so far he is connected with.

Naipaul's consciousness of being a Brahmin is evoked when he notices the Brahmin women. He writes, "In 
their feature I could recognize those of the women of my family" [1]. Being uneasy of his with his ambivalent state he always tries to remind himself about the Hindu origin and beliefs and customs of his Indian ancestors in Trinidad. When he looks at the images of shrines he writes, "My mind leapt years, my sense of distance and time was shaken; before me were the very few replicas of the images in the prayer room of my grandfather's house" [1].

Naipaul is able to make a connection physically but the problem is how to put them in one frame. He realizes how reluctant he is and confesses when he said, "I had come to them reluctantly. I had expected little and I had been afraid. The ugliness was all mine" [1].

Sometimes he likes to be associated with India and sometimes not. There is at times a distance and at times attachment. He cannot love the country of his origin, at the same time he could not reject it. This ambivalent attitude towards India kindles him to make a series of visit. The task of making visits to India evolves him an interpreter of India to the Western audience. His peculiar position is explicit in the words of Mc Sweeney, "... precisely because he is so uniquely qualified- by his Indian ancestry. Trinidad childhood, British base, and temperamental inability to stay in one place for long" [4].

Naipaul attempts to understand India on his every visit. His change of attitude gets reflected not only in the title but also the reading of the book India: A Wounded Civilization confirms it.

Apart from his experiences, he also takes this opportunity to showcase to the West. In all ways Naipaul's each visit to India develops his understanding of the realities of the place, people and issues. The next book India: A Million Mutinies Now illustrates this view point more explicitly.

\section{Quest for His Origin}

More compassionate Naipaul during his third visit finds that the country has changed enormously. In India: A Million Mutinies Now he has come to accept the reality of the country of his ancestors. His attitude towards this country has changed, he writes:

In 27 years I had succeeded in making a kind of return journey, shedding my Indian nerves, abolishing the darkness that separated me from ancestral past...my ancestors had left as indentured servants for the sugarcane estates of Guyana and Trinidad. I had carried in my bones that idea of objectless feat and shame...
What I hadn't understood in 1962, or had taken too much for granted, was the extent to which the country had been remade; and even to the extent to which India had been restored to itself [5].

This attitudinal change rightly proves the fact that his commitment is to his own vision and expression of life. It becomes imperative for a writer to transcend the limits of place and time and achieve universality. Naipaul as a cosmopolitan, looks at India more of a country as a whole but one could not neglect the fact that his association with India because of his origin which drives him frequently. But the perspective of a writer keeps on changing which frames the basis of a postmodern writer. Naipaul is of no exception to it, who comes to terms with not only to India but to the world as such. This provides him space to retrace his steps and amend his previous rage. $\mathrm{He}$ understands that his ignorance and darkness is not about the place but the knowledge he has on the country. To quote from Naipaul's interview with Aamer Hussain, he says, "That book on India (India: A Million Mutinies Now) is not oral history... The idea came to me that the truth about India wasn't what I thought about India, It's what they a living through" [6].

Naipaul visits India to understand better and to fulfil the things that he had left in the earlier visits. He meets a lot of people and moves to different places. He meets Muslims in Bombay, Sikhs in Punjab, Dalit Panther movement and Shiv Sena activists. Being a member of minority in Trinidad, Naipaul understood the dilemma of the minorities in India and sympathizes with them. He states that all these are inevitable and writes, "Independence had come to India like a kind of revolution; now there are many revolutions within that revolution. What was true of Bombay was true of other parts of India as well: of the state of Andhra, of Tamil Nadu, Assam, Punjab" [5].

Attitudinal shift of Naipaul makes him look at the physical reality of India and its challenges and short comings and understands the significance of the people, their practices and the social setup and values them. He is able to make meaningful connection with his past. He should not be misunderstood for his opinion on physicality of the place because his Western life would definitely bring forth such a response. Moreover the kind of satisfaction that he attains after witnessing the similarities of his early life with the life of Indian people and their practices is worth all the effort in fixing his origin. There is a paradigm shift in his focus and outlook when he realises the changing realities of the place. He has become more aware of modern India. 


\section{Conclusion}

V.S. Naipaul in his book, Finding the Centre states that he "travels to discover other states of mind" [7]. He moves from unknowing to knowing and understands people and places alien to him. The characters drawn from life and by interaction with people shunted between two opposite worlds marked by orthodox Hindu faith of his ancestors and rationalism of the West make him negotiate with the places he visited. Rediscovering the mythical truth of India from the innermost fibre of his self forms the centre of Naipaul's creative impulse. Hence the Trilogy on India forms a basis of his personal search for an external pattern. His journey into darkness in the beginning becomes a learning process. His first visit to India results in a shocking experience. The atmosphere of dirt and squalor makes him to consider the place as an area of darkness, contrary to his memories of India. This conflict makes him realize how things are different from what he has thought of India. Later on realisation comes on him about the significance of the nation and its universality which forms the secret of its survival.

\section{References}

1. Naipaul V.S. An Area of Darkness. 1964. London: Harmondsworth: Penguin Books, 1968. pp. 27.

2. "Two Worlds: The 2001 Nobel Lecture". World Literature Today, quarterly Univ. of Oklahoma 76. 2 (Spring-2002): 8.

3. India: A Wounded Civilisation. Delhi: Vikas, 1977. pp. 8-9.

4. Mc Sweeney K. Four Contemporary Novelists. London: Scolar Press, 1988. pp. 154.

5. Naipaul V.S. India: A Million Mutinies Now. London: Minerva, 1990. pp. 516-17.

6. Naipaul V. S, Interview by Aamer Husain. Delivering the Truth. The Literary Supplement of The Hindu. 2 October 1994: 6.

7. Naipaul V.S. Finding the Center. Canada: Penguin Books, 1985. pp. 87. 